\title{
The Transformation of Gender Role in Coastal Area of Teluk Bakau
}

\author{
Diah Siti Utari ${ }^{1}$, Rianto $^{2}$, Miswanto $^{3}$, Desmayeti Arfa $^{4}$ \\ \{diahsitiutari08@gmail.com ${ }^{1}$, awang.rianto2013@gmail.com ${ }^{2}$, miswanto0584@gmail.com ${ }^{3}$, \\ desma4@gmail.com $\left.{ }^{4}\right\}$ \\ STISIPOL Raja Haji, Indonesia ${ }^{1,2,3,4}$
}

\begin{abstract}
Teluk Bakau is a village which is located in the coastal area and has the potential of fisheries natural resources and beautiful natural panoramas. The purpose of the research is to know the transformation of fishermen's wife role in the island. The research methods are descriptive qualitative and explorative which used data collection techniques through participant observation and in depth interview. The sampling technique used is purposive sampling. Informan in this research are the women who have already had husband and run job as fishermen. They are about 15 persons. The result of this research explains that the development in the coastal area has an impact on the transformation of gender roles with the women's involvement actively in the activities' organization, the activities of an economic nature either creative business or engaged in a company activity.
\end{abstract}

Keywords: Transformation Gender of Role, Coastal Area

\section{Introduction}

Development is an effort which is carried out consciously and sustainably to strive for community change, not only in a social economic but also in a multidimensional context. The development paradigm offers an alternative choice of development's model which is adapted with the special conditions of an area that is currently known as coastal development. Coastal area is an area that contains natural resources both in land and ocean which are required to meet human needs. The development of coastal areas is needed not only in the context of socioeconomic change but also to increase the role of community members. With its tribal diversity population composition, the dynamics of social interactions and development processes can be seen from Figure 1. 


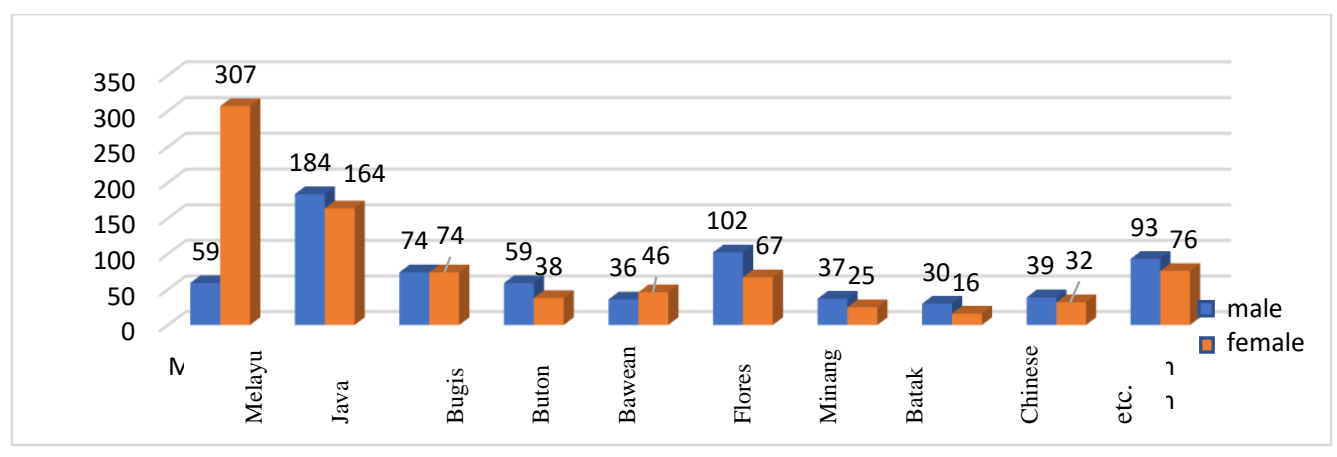

Fig 1. The community's amount based on gender in Teluk Bakau village. Gunung Kijang sub district year of 2016

Source: Badan Pusat Statistik (BPS) or Central Bureau of Statistic of Bintan Regency, 2016

Furthermore, the employment's condition in coastal villages such as Teluk Bakau is dominated by fishermen, government officers, and businessmen. In accordance with the development's implementation, Teluk Bakau is as one of the tourism villages gradually changed by increasing its business activities in tourism sector with its productive economic businesses and the greater role of women including the fishermen's wife in Teluk bakau village. The purpose of this research is to find out the role transformation carried out by women, especially the fishermen's wife in Teluk Bakau village in accordance with the development process in the area.

According to [1] development is an intentional or conscious changing process to achieve a positive result for whole community members [1]. The changing through the development process principally is to improve the community living's standard. According to Soekanto, development process includes the development plan and the development process, increasing productivity, increasing living standards, roles, equal and equal opportunities in politic, social, and economic fields and law, development and attitudes in society such as efficiency, perseverance, determination, simplicity, honesty, logical in decision making, always ready to face the change, always use the opportunity properly, be active in business, has integrity and independent, and be cooperative [2].

The development implementation is oriented to improve the living standard which focuses on strengthening the sectors which become the region mainstay and one of them is related to the coastal areas' development. According to Adisasmita that Coastal area development is one of the elements in strategic maritime development that should be given proportionally because it has the potential and prospective marine and fisheries resources and involves about $50 \%$ of Indonesia total population related to the maritime socio-economic activities. Coastal communities in Indonesia live along the wide beaches which have a very strategic and potential role and they usually are fishermen [3].

The continuing development in an area has an impact which cannot be avoided, they can change both the role and the status or status arise.

According to [4] the role is the expected someone's behavior who has status. Status in this case is the position of a person in a group or the position of a group in relation to other groups. Roles are also interpreted as playing a role in the set of obligations and rights [4]. And someone can have a set of roles, in other words, everyone can have many roles that are appropriate to their status. 
Furthermore, [2] states that role is a dynamic position aspect from each community member. if someone carries out his rights and obligations as suit to his position, he will be considered as someone who has carried out his role. If someone occupies a position in the community and carries out a role, there are 3 (three) matters concerning the role, they are:

1. The role includes norms which are related to one's position or place in society. The role in this sense is a series of rules that guide a person in social life

2. Role is a concept of what can be done by individuals in society as an organization

3. Role can also be said to be individual behavior that is important for the society social structure [2].

The role of women is not only as a wife in a family but now, she has a changing transformation who is involved in various activities and public through their involvement outside of home. In the public sphere, especially in the field of work, gender issues can be seen from the differences treatment based on the quantitative and qualitative gap formations in terms of division of labor / secretion. It was stated by More and Sinclair Sunarto that in the world of work there can be a gap between men and women in the form of vertical and horizontal segregation. Vertical segregation refers to the concentration of women in a low level in an organization and horizontal segregation which refers to the different types of work that women workers receive [5].

\section{Method}

This type of research uses a qualitative approach, using data collection through participant observation and in-depth interviews with informants. By using purposive sampling technique, the informants in this research were the women who were also fishermen's wife in Teluk Bakau village. Analysis is carried out based on the field findings and theoretical studies used.

\section{Result and Discussion}

In the research, there was a role transformation carried out by women in Teluk Bakau village which could be grouped into domestic and public roles. Domestic roles are related to the role played by women as fishermen's wives in Teluk Bakau village. Whereas the public role is related to the role and activities carried out outside of their homes. Based on the research that the women's role as fishermen's wives in Teluk Bakau village.

\section{Role as a wife}

As a family, the fishermen's wife in Teluk Bakau village have a similar family life in general. The families who have children, they do their daily routine works. Based on the observations in the field of women's activities as fishermen's wife, they carry out the daily activities such as cooking, delivering and picking up their children, accompanying their children at night and some of them are active in various organizations, attending reading Qur'an in the mosque near their neighborhood. However, they sometimes spend their free time doing activities to take snails and shells on the seashore which are often called "Merompong". The results can be sold or fulfill their daily needs. 
Role as a leader / motivator / activator

There are several organizations formed in Teluk Bakau village which are consists of women. They are as table 1 .

Table 1. The women involved in Organizations In Teluk Bakau village

\begin{tabular}{|c|l|c|}
\hline NO & \multicolumn{1}{|c|}{ Organization Name } & Information \\
\hline 1 & $\begin{array}{l}\text { Perlindungan Anak Terpadu Berbasis Masyarakat (PATBM) } \\
\text { or Community-based Integrated Child Services }\end{array}$ & Active \\
\hline 2 & Kelompok Tani Wanita (KWT) or Women's Farmer Group) & Active \\
\hline 3 & Kelompok Usaha Bersama (KUBE) or Joint Business Group & Active \\
\hline 4 & $\begin{array}{l}\text { Usaha Peningkatan Pendapatan Keluarga Sejahtera } \\
\text { (UPPKS) or Prosperous Family Income Revenue Unit }\end{array}$ & Active \\
\hline 5 & Taruna Siaga Bencana (Tagana) or Disaster Response Team & Active \\
\hline 6 & Study Group & Active \\
\hline 7 & $\begin{array}{l}\text { Pendidikan Anak Usia Dini (PAUD) or Early Childhood } \\
\text { Education group }\end{array}$ & Active \\
\hline 8 & Reading Gardens & Active \\
\hline 9 & Women's Cooperative named "Rosella" & Active \\
\hline
\end{tabular}

Based on the table 1, it can be explained that the village of Teluk Bakau is one of the villages that many different organizations have been formed, organizational leadership only relies on the same group of women. The role of female leaders in this group is very large in mobilizing members of organizational groups and community members. The value of togetherness to participate and mobilize all aspects including institutions / organizations that have been formed in the community in the process is very necessary. So that, the sustainability of the organization and the regeneration process in creating organizational leadership, especially women, can be continued. This condition will also have an impact on increasing their role as development's motivator in Teluk Bakau village.

\section{Role as entrepreneur}

Based on the role of women in Teluk Bakau Village, several women who were successfully interviewed stated that they took the opportunity to create jobs to help their husbands by utilizing the available natural resources in Teluk Bakau village and its surrounding areas by making alang-alang (reed) roofs. Alang-alang roof is needed as a cover for baligo. Baligo is usually built as a resting place for tourists who come and stay at hotels or resorts along the beaches of Trikora, Lagoi, Bintan Agro and some areas outside Bintan island such as Nikoi island and islands which are owned and managed by Resort entrepreneurs.

If we look at from the production process of alang-alang roof, it is easy to make, and the market price is higher between $\mathrm{Rp} 15,000$ to $\mathrm{Rp} 30,000$, it depends on the design of the production's interest.

In one day, the production of alang - alang roof can reach up to 40 sheets. Until now, women who live in certain neighborhood still carry out production activities even though manually. At present the demand for alang-alang roof is very high due to the growing number of new resorts and hotels.

Based on findings in the field data also shows the existence of other business activities carried out by women including the fishermen's wife of who are active in groups assisted by the Badan Kependudukan dan Keluarga Berencana Nasional (BKKBN) or State Ministry for 
National Family Planning Coordinating Board. The assisted groups referred to the Kelompok Usaha Bersama (KUBE) or Joint Business Group which was fostered by the Social Civil Registry Office and Usaha Peningkatan Pendapatan Keluarga Sejahtera (UPPKS) or Prosperous Group Income Improvement Efforts which was fostered by the State Ministry for National Family Planning Coordinating Board. Although in reality in the field it was found that there were groups of women who were almost the same as movers in different groups, but especially in the Prosperous Group Income Improvement Efforts group named "Rosella", activities with the women by making fried onion cakes were unique. Prosperous Group Income Improvement Efforts "Rosella" currently has a group business of making fried onion cakes with natural dyes and natural flavors, namely kelo leaves, dragon fruit and spinach. Further utilization of these fruits and vegetables productions in making fried onion cakes are a good thing considering the availability of these plants is quite available around Teluk Bakau and other villages that are still in Gunung Kijang sub district, this condition is based on the secondary data (Table 2 and Table 3).

Table 2. Planted Area of Vegetables by Kind and Sub District in Bintan Regency 2017

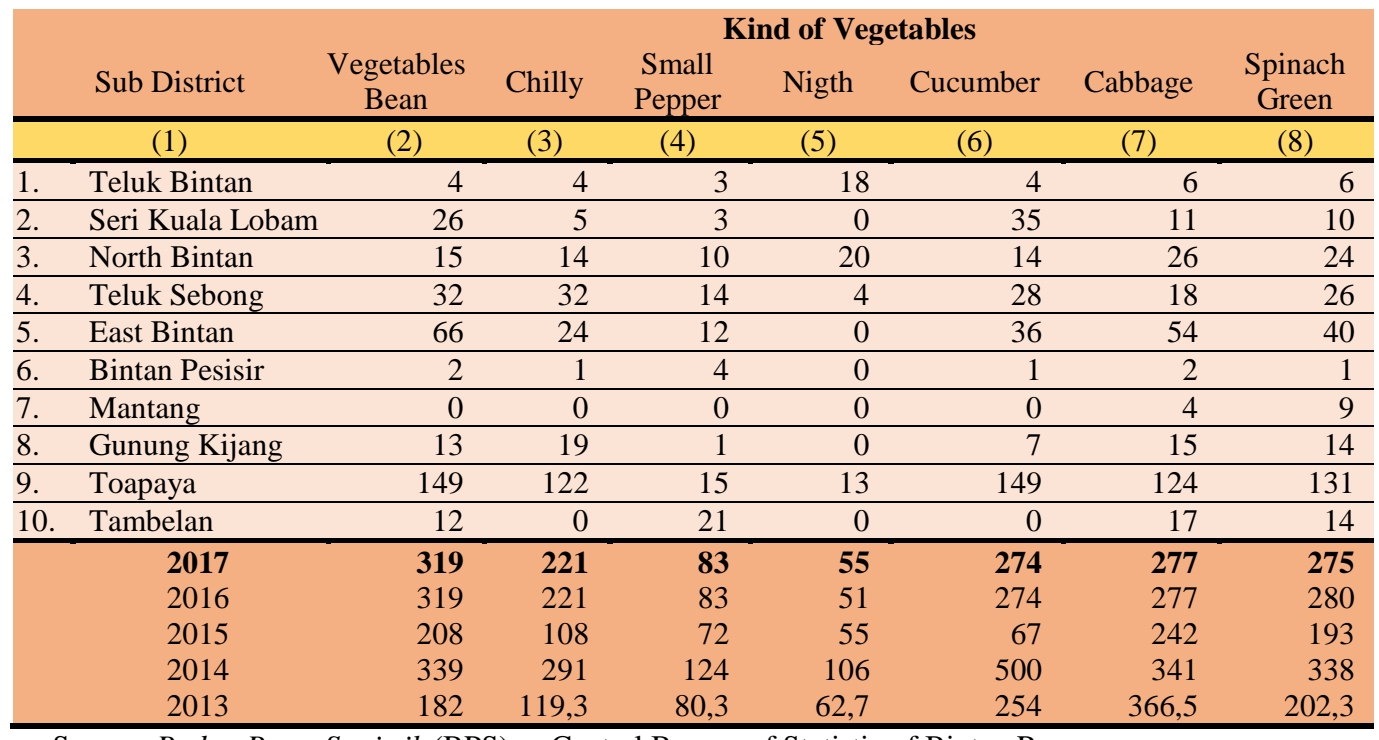

Source: Badan Pusat Statistik (BPS) or Central Bureau of Statistic of Bintan Regency

The availability of dragon fruit is also one of the ingredients for making cakes produced by Prosperous Group Income Improvement Efforts "Rosella". Based on 2015 Bintan regency statistical data, dragon fruit production in rural villages in Gunung Kijang district is 2.95 tons. Based on the direct observation to the manufacturing location, there are problems in marketing considering the cake expiration period is relatively fast (approximately 10 days) and can produce an average of 30-40 in one month because no preservatives are used, so if marketed in nearby shops Teluk Bakau village certainly does not have an impact on increasing production. Meanwhile, to be marketed outside the village of Teluk Bakau requires production costs. In addition, the underdevelopment of the business being carried out is due to limited capital and production management, such as cake product packing. One common problem that is also 
experienced by businesses that are jointly managed by the home industry also concerns the display of halal certification on products. While for this purpose a substantial cost is needed.

Table 3. Harvested Area of Vegetables by Kind and Sub District in Bintan Regency, 2017

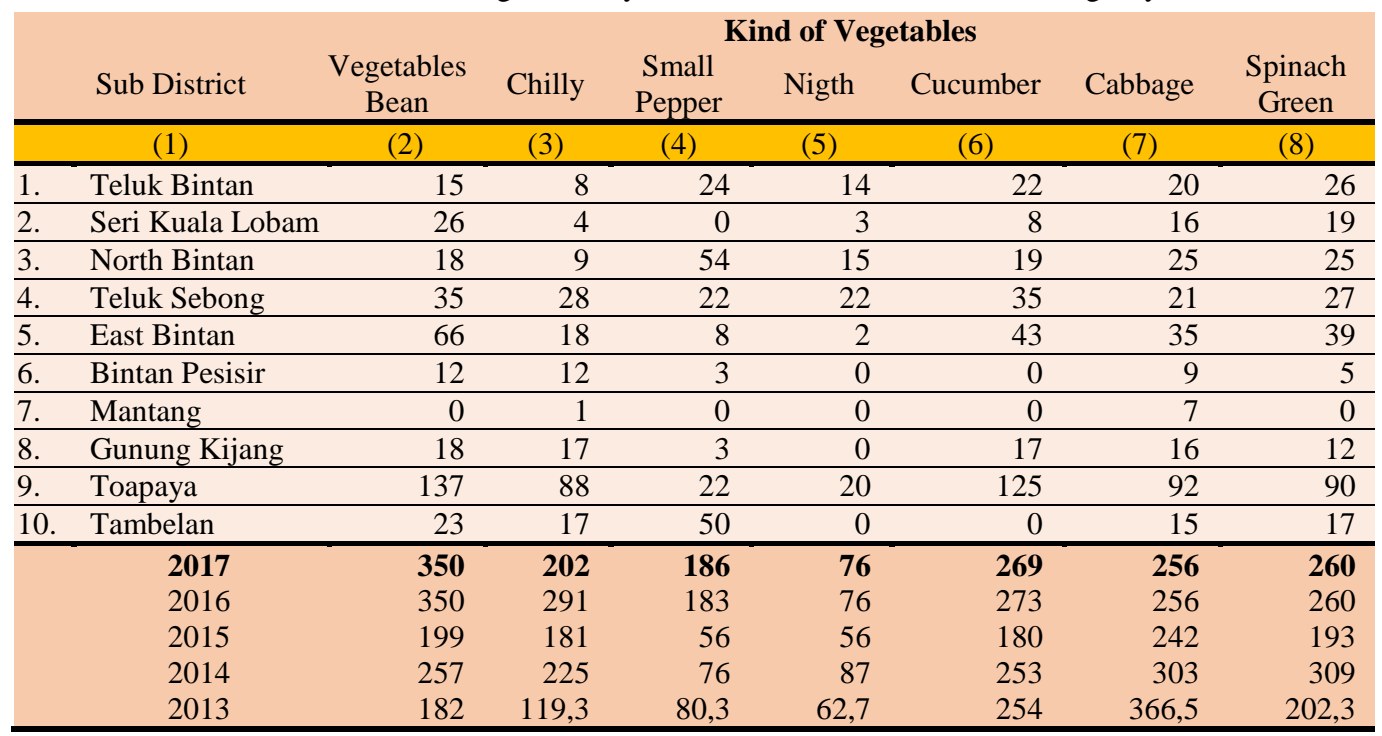

Source: Badan Pusat Statistik (BPS) or Central Bureau of Statistic of Bintan Regency

\section{Role as a worker Labor}

Tourism development has increased gradually to support the tourism businesses such as hotels and resorts. By increasing more activities for hotel business and resorts which are located in Bintan Island and particularly in Teluk Bakau village, it influenced the changing of women's role which were originally housewives and fishermen's wives, but nowadays they choose to work at a resort or hotel where closed to their live. Based on the field data, there were many fishermen's wife in Teluk Bakau village who ultimately chose to do work to help their family's income by working in some resorts or hotels around Teluk Bakau village but they did not occupy a position in the management structure. They work as employees who handle the room massages, room cleaning service (as room girls), and chef for hotel's employees. This condition forced them to hope that there will be an additional income which can help family's economic needs.Based on the field data, female workers in massage or spa section have 10 working hours in a day and 6 days a week. They get Rp 80,000 per day for their salary except overtime activities. In a full of tourist arrivals occupancy, especially foreign tourists, the employees often work overtime with the incentive of $\operatorname{Rp} 25,000$ for a massage theraphist and $\mathrm{Rp} 8,000$ per hour for overtime activities. Furthermore, some women who worked for employees' canteen (as a chef) also felt that they earned a quite big salary about Rp 75,000 for a day even though there was one informant who explained that they had worked without day off in a month. Based on Central Bureau of Statistic of Bintan Regency in 2016 there were 11 tourists' inns and some of them are located around Teluk Bakau which would require special workers such as spa or massage therapists which can be seen in the table 4 . 
Table 4. Number of Accommodation/Hotel, Rooms and Beds Available by Sub District in Bintan Regency, 2017

\begin{tabular}{llrrrr} 
& Sub District & Hotels & \multicolumn{2}{c}{ Rooms } & Beds \\
\hline & \multicolumn{1}{c}{$(1)$} & $(2)$ & $(3)$ & 30 & $(4)$ \\
\hline 1. & Teluk Bintan & 1 & 0 & 38 \\
\hline 2. & Seri Kuala Lobam & 0 & 127 & 0 \\
\hline 3. & North Bintan & 4 & 2.048 & 3.015 \\
\hline 4. & Teluk Sebong & 17 & 73 & 85 \\
\hline 5. & East Bintan & 3 & 0 & 0 \\
\hline 6. & Bintan Pesisir & 0 & 0 & 0 \\
\hline 7. & Mantang & 0 & 530 & 1,023 \\
\hline 8. & Gunung Kijang & 12 & 36 & 96 \\
\hline 9. & Toapaya & 1 & 0 & 0 \\
\hline 10. & Tambelan & 0 & $\mathbf{2 . 8 4 4}$ & $\mathbf{4 . 3 9 9}$ \\
\hline & $\mathbf{2 0 1 7}$ & $\mathbf{3 8}$ & 2.345 & 4.690 \\
& 2016 & 38 & 2.501 & 3.898 \\
& 2015 & 32 & 1.983 & 2.298 \\
& 2014 & 35 & 2.462 & 3.549 \\
\hline
\end{tabular}

Source: Badan Pusat Statistik (BPS) or Central Bureau of Statistic of Bintan Regency

Beside the transformation of gender roles, women in Teluk Bakau village had a unique character such as having brave to determine the decision, sensitive in economic opportunities, and many more. As informants, women in Teluk Bakau village need to continue to be involved in various activities in organization so that the cadres can grow it sustainability and the community development can be achieved in the future.

Moreover, in order the women who carry out their roles through activities in public sector can provide optimal achievements, there must have ongoing guidance, mentoring and supervision from government so that they can provide the protection and insurance for the workers sustainably from the business activities which they undertake.

\section{Conclusion}

Wherever and whatever the business, there is a problem in adopting media technology, so that the district government initiatives are needed to provide it. The district government is also the administrator of the management of web-based applications and Short Message Service gateways because broadband district access is available in the district capital. Thus, the obligatory passage point (see figure 2) is the first step in overcoming barriers between seller and buyer relations. Presenting web-based applications and Short Message Service gateways complement the limitations of telephone performance, as well as the actions of the district government as web-based application and Short Message Service gateways providers and administrators. 
In the future, research needs to be sought to match media technology that not only promotes superior products in the village market but also other needs. Web-based applications may provide a variety of information as needed, a window of information on resources, culture, and other important issues [3]; such as promoting tourism, security needs, and others. Teluk Bakau as one of the coastal villages in Bintan Island and become one of the marine tourism villages has already changed in the socio-economic community's aspects as a development's consequence which has been passed so far.

The women, especially fishermen's wives have already got transformation role from just become as housewives to women who have had various social and economic activities and they have already had the awareness to be involved in a social interaction activities both as leaders of an organization who motivate the community, especially women, as community leaders, actors in economic activities independently and collectively both as actors and workers.

Acknowledgements. The authors would like to thank the reviewers, especially to Universitas Muhammadiyah Sidoarjo (UMSIDA) that hold the International Conference on Emerging Media, and Social Science December 7-8, 2018 Banyuwangi, Indonesia.

\section{References}

[1] Damsar, Pengantar Sosiologi Perdesaan. Jakarta: Kencana, 2016.

[2] S. Soekanto, Sosiologi Suatu Pengantar. Jakarta: Rajawali Pers, 1990.

[3] R. Adisasmita, Pembangunan Wilayah. Yogyakarta: Graha Ilmu, 2014.

[4] P. B. Horton, Sosiologi. Jakarta: Penerbit Erlangga, 1999.

[5] K. Sunarto, Pengantar Sosiologi. Jakarta: LPFE UI, 2004. www.adweek.com/socialtimes/81-shoppers-conduct-online-research-making-purchaseinfographic/208527. [Accessed: 02-Aug-2018]. 